Technical Report

\title{
Experimental study of insulating properties and behaviour of thermal barrier coating systems in thermo cyclic conditions
}

\author{
Mihailo Mrdak $^{\mathrm{a}}$, Marko Rakin ${ }^{\mathrm{b}}$, Bojan Medjo $^{\mathrm{b}, *}$, Nikola Bajić $^{\mathrm{c}}$ \\ ${ }^{a}$ Research and Development Center, IMTEL Communications a.d., Belgrade, Serbia \\ ${ }^{\mathrm{b}}$ Faculty of Technology and Metallurgy, University of Belgrade, Karnegijeva 4, 11120 Belgrade, Serbia \\ ${ }^{\mathrm{c}}$ IHIS Techno Experts Research and Development Center, IHIS Science E' Technology Park, Belgrade, Serbia
}

\section{A R T I C L E I N F O}

Article history:

Received 11 September 2014

Accepted 21 November 2014

Available online 27 November 2014

\begin{abstract}
A B S T R A C T
The aim of this study was to improve the resistance of turbo jet engine parts exposed to high temperatures and overheating and sudden changes in temperature. For this purpose, three thermal barrier coating (TBC) systems $\mathrm{NiCrAlCoY} \mathrm{O}_{3} / \mathrm{ZrO}_{2} \mathrm{MgO}$, NiCrAlCoY $\mathrm{O}_{3} / \mathrm{ZrO}_{2} \mathrm{Y}_{2} \mathrm{O}_{3}$ and $\mathrm{NiCrAlCoY} \mathrm{O}_{3} / \mathrm{ZrO}_{2} \mathrm{CeO}_{2} \mathrm{Y}_{2} \mathrm{O}_{3}$ were tested. They were deposited using the atmospheric plasma spray process (APS). In order to develop a TBC with the best thermal insulating properties and the highest reliability in relation to aging of materials under the influence of sudden changes in temperature, TBC systems that were deposited on cold and preheated substrates were tested. The network of microcracks on the surfaces of the ceramic layers in deposited condition was analyzed using scanning electron microscopy (SEM). Insulating characteristics of TBC systems were examined by measuring the temperature difference $\Delta T$ between the top and bottom surfaces of the samples at a temperature of $1200^{\circ} \mathrm{C}$. Testing of TBC for resistance to thermal cyclic behaviour was performed by exposing samples to alternate heating at $1200^{\circ} \mathrm{C}$ and rapid cooling of the samples to $180^{\circ} \mathrm{C}$. Microhardnesses of the TBC system, after completion of thermal cycles, were compared with the values in deposited state. Analyses of thermal insulation properties and thermal cyclic behaviour have shown a correlation between the substrate temperature and quality of the TBC system in thermal cyclic conditions.
\end{abstract}

(C) 2014 Elsevier Ltd. All rights reserved.

\section{Introduction}

The increasing demand for improving the efficiency of gas turbine parts of turbo-jet engines, both in the civilian and military sector, led to the development of new materials for thermal barrier coatings (TBC). The need to develop TBC systems resulted from the more stringent conditions of the new generation of gas turbines and higher temperatures of gases [1] (of course, they are also used in other industries, e.g. in automotive industry for spark ignition engine production [2]). Parts of the gas turbines are exposed to high-temperature oxidation, hot corrosion, gas erosion and foreign particle emissions, as well as rapid changes in temperature. The TBC should not only limit heat transfer through the coating, but also protect engine components from oxidation and hot corrosion.

No single coating is able to fulfil these multifunctional requirements. As a result, a coating system was developed consisting of two or three coatings in order to achieve long-term efficiency at high temperatures, oxidation and corrosion protection of the base material. TBC systems are the only class of materials that can be

\footnotetext{
* Corresponding author. Tel.: +381 113303 876; fax: +381 113370387.

E-mail address: bmedjo@tmf.bg.ac.rs (B. Medjo).
}

applied to such working conditions [3]. Typical thermal barrier coatings for gas turbines and diesel engines consist of a top layer of $\mathrm{ZrO}_{2}$ stabilized by other oxides and bond coating of NiCrAlY [4]. The basic material for making the ceramic thermal barrier coating layer is $\mathrm{ZrO}_{2}$ oxide.

Selection of $\mathrm{ZrO}_{2}$ compared to other oxides was done because of good mechanical properties (high strength and fracture toughness) and physical properties, such as thermal conductivity $(\lambda \approx 1.7 \mathrm{~W} /$ $\left.\mathrm{m}^{\circ} \mathrm{C}\right)$, thermal expansion coefficient $\left(\alpha \approx 9 \times 10^{-6} 1 /{ }^{\circ} \mathrm{C}\right)$ and melting temperature of $2710^{\circ} \mathrm{C}[5,6]$. An important feature of pure $\mathrm{ZrO}_{2}$ is polymorphism [7]. At atmospheric pressure, there are three crystallographic phases: monoclinic, tetragonal and cubic. When alternating heating and cooling, thermal fatigue of $\mathrm{ZrO}_{2}$ material occurs due to volume changes caused by phase transformation.

As a result of the reversible transformation of the monoclinic to the tetragonal phase in the temperature range of $950-1170^{\circ} \mathrm{C}$, occurrence of microcracks that spread and turned into macro cracks was observed $[8,9]$. For this reason, pure $\mathrm{ZrO}_{2}$ is not suitable for the production of thermal barrier coatings. In order to reduce the effect of tetragonal to monoclinic transformation, other oxides are added to pure $\mathrm{ZrO}_{2}$, such as $\mathrm{CaO}, \mathrm{MgO}, \mathrm{Y}_{2} \mathrm{O}_{3}$ and recently $\mathrm{CeO}_{2}$, $\mathrm{HfO}_{2}$, and $\mathrm{In}_{2} \mathrm{O}_{3}$. These additions stabilize the ceramic layer 


\section{Nomenclature}

$\alpha \quad$ thermal expansion coefficient $\left(1 /{ }^{\circ} \mathrm{C}\right)$

$\Delta T_{u} \quad$ temperature difference through the sample in the direction perpendicular to the substrate surface $\left({ }^{\circ} \mathrm{C}\right)$

$\Delta T_{s} \quad$ temperature difference in the top and bottom surfaces of the substrate $\left({ }^{\circ} \mathrm{C}\right)$
$\Delta T_{T B C} \quad$ temperature difference through the layers of TBC system $\left({ }^{\circ} \mathrm{C}\right)$

$\lambda \quad$ thermal conductivity $\left(\mathrm{W} / \mathrm{m}{ }^{\circ} \mathrm{C}\right)$

$\mathrm{HV}_{0.1} \quad$ Vickers microhardness of layers of the TBC system, obtained using 100 gram load (-) partially or completely by forming a cubic structure which is stable from room temperature up to over $2000^{\circ} \mathrm{C}$. Stabilization, full or partial, in which the tetragonal or monoclinic phases also occur with a cubic phase, depends on the type and amount of added oxides. TBC systems have a dual role. The first role of TBC is to provide working ability of the base material at temperatures above the limits of its endurance, by lowering the actual temperature on the bottom surface of the bond layer of the TBC system for $\Delta T=200$ $400{ }^{\circ} \mathrm{C}$ [10]. In addition, it has to keep low thermal conductivity during prolonged exposure in working conditions. This coating is, when comparing thermal coefficients, different from the component to which it is applied. This layer should be coordinated with the base material through the bond layer. Secondly, the coating should protect the base material from oxidation and gas corrosion, which is emphasized at high temperatures in a gas turbine.

This layer needs to keep its properties and remain stable over long exposure to heat stress and avoid premature destruction of the TBC system. The lower bond layer, which is thinner than the ceramic layer, provides protection of the substrate against oxidation and hot corrosion. For the preparation of the bond layer, an alloy type MeCrAlY is used, where Me can be $\mathrm{Co}, \mathrm{Ni}$ or Fe. The metal layer must be well connected to the substrate, preventing diffusion on the interface, increase corrosion resistance and reduce the influence of residual stresses in the ceramics [11-14]. The main problem of deposited TBC systems on metal substrates is the possibility of failure when it comes to thermal load. Sudden temperature changes can cause cracking and separation of the entire TBC system from the substrate due to significant differences of linear expansion coefficients of ceramics and metals.

The separation of TBC layers along the edges can occur as a result of the temperature gradient in the marginal zone. On the surface of the ceramic coatings, the networks of microcracks are formed due to compressive stress induced by phase transformations accompanied by volume changes [15]. Networks of microcracks tend to connect with the number of thermal cycles, and cause segment separation of ceramic particles from the surface [16].

In this paper, three types of TBC systems $\left(\mathrm{NiCrAlCoY} \mathrm{O}_{3} / \mathrm{ZrO}_{2}\right.$ $\mathrm{MgO}, \mathrm{NiCrAlCoY} \mathrm{O}_{3} / \mathrm{ZrO}_{2} \mathrm{Y}_{2} \mathrm{O}_{3}$ and $\left.\mathrm{NiCrAlCoY} \mathrm{O}_{3} / \mathrm{ZrO}_{2} \mathrm{CeO}_{2} \mathrm{Y}_{2} \mathrm{O}_{3}\right)$ were tested in thermal cyclic conditions to determine which coating system provides the greatest temperature drop through the layer. In order to develop a TBC with the best thermal insulating properties and the highest reliability in relation to aging of materials under the influence of sudden changes in temperature, TBC systems deposited on cold and preheated substrates were tested. Analyses of the results of the examinations allowed choosing TBC systems with the best thermal insulating properties and highest reliability.

\section{Materials and experimental details}

Materials for testing are TBC systems that are deposited on steel substrates of stainless steel X15Cr13 (EN 1.4024). Coatings systems were deposited with atmospheric plasma spraying using powders: Metco 461NS ( $\mathrm{NiCr}-\mathrm{Al}-\mathrm{Co}-\mathrm{Y}_{2} \mathrm{O}_{3}$ ), Metco 210 ( $\left.\mathrm{ZrO}_{2} \mathrm{MgO}\right)$, Metco
202NS $\left(\mathrm{ZrO}_{2} \mathrm{Y}_{2} \mathrm{O}_{3}\right)$ and Metco 205NS $\left(\mathrm{ZrO}_{2} \mathrm{CeO}_{2} \mathrm{Y}_{2} \mathrm{O}_{3}\right)$ [17-20]. Three ceramic powders with different thermal conductivity coefficients were used, as follows: $\mathrm{ZrO}_{2} \mathrm{MgO}$ with thermal conductivity coefficient $1.5 \mathrm{~W} / \mathrm{m}^{\circ} \mathrm{C}, \mathrm{ZrO}_{2} \mathrm{Y}_{2} \mathrm{O}_{3}$ with thermal conductivity coefficient $1.3 \mathrm{~W} / \mathrm{m}^{\circ} \mathrm{C}$ and $\mathrm{ZrO}_{2} \mathrm{CeO}_{2} \mathrm{Y}_{2} \mathrm{O}_{3}$ with thermal conductivity coefficient $0.9 \mathrm{~W} / \mathrm{m}^{\circ} \mathrm{C}$. In the experiment, these systems were tested: TBC system 1 ( $\left.\mathrm{NiCrAlCoY}_{2} \mathrm{O}_{3} / \mathrm{ZrO}_{2} \mathrm{MgO}\right)$, TBC system 2 $\left(\mathrm{NiCrAlCoY}_{2} \mathrm{O}_{3} / \mathrm{ZrO}_{2} \mathrm{Y}_{2} \mathrm{O}_{3}\right)$ and $\mathrm{TBC}$ system $3\left(\mathrm{NiCrAlCoY}_{2} \mathrm{O}_{3} / \mathrm{ZrO}_{2}\right.$ $\left.\mathrm{CeO}_{2} \mathrm{Y}_{2} \mathrm{O}_{3}\right)$. The same bonding layer $\left(\mathrm{NiCrAlCoY} \mathrm{O}_{3}\right)$ was used for all the TBC systems. It was selected because it belongs to the new generation of bonds, and it has been widely used due to the good thermo-mechanical properties. Its important advantage is pronounced toughness.

Labels of tested samples, total thickness of the coatings and amount of pores in the ceramic layers were: for TBC system 1 samples $(2-1) /(2-2)$, thickness $(504 \mu \mathrm{m} / 490 \mu \mathrm{m})$, amount of pores (24\%/14\%), for TBC system 2 samples $(3-1) /(3-2)$, thickness $(420 \mu \mathrm{m} / 406 \mu \mathrm{m})$, amount of pores $(29 \% / 23 \%)$, for TBC system 3 samples $(4-1) /(4-2)$ thickness $(490 \mu \mathrm{m} / 476 \mu \mathrm{m})$ and amount of pores $(29 \% / 23 \%)$. For TBC deposited on substrates with temperatures of $21-23^{\circ} \mathrm{C}$, the labels are (2-1), (3-1) and (4-1), and on substrates with temperatures of $160-180^{\circ} \mathrm{C}$ the labels are (2-2), (3-2) and (4-2).

Testing for presence of microcracks on the surfaces of ceramic layers was carried out on samples with dimensions $70 \times 2$ $0 \times 1.5 \mathrm{~mm}$. The presence of microcracks on the surfaces of the ceramic coatings after depositing powders was examined by scanning electron microscopy (SEM), in order to determine their effect on the behaviour and durability of the TBC in thermal cyclic conditions. Thermal insulation properties of TBC systems were investigated by measuring the temperature difference $\Delta T_{u}$ through the sample in the direction perpendicular to the substrate surface. $\Delta T_{u}$ values for the sample are obtained by measuring the surface temperature of the TBC and the bottom surface of the substrate. This method is usually applied for stationary conditions and, above all, it provides information on the temperature drop through the thickness of the TBC. Samples for testing of thermal barrier coatings are made by pairing two samples of the same type of TBC-s which were deposited on substrates with different temperatures. Between the samples, a metal plate was positioned. The inner thermocouple passed through this plate, measuring the temperature of the bottom surface of the substrate.

The external thermocouple was placed on the upper surface and at the same distance as the internal thermocouple which measured the temperature on the upper surface. Connecting of the samples was done with stainless steel bolts that were protected by thermal barrier. Internal and external thermocouples were separated by alumina ceramic tubes that went through a larger ceramic tube. That tube was used as a sample holder. For sealing the furnace, a cap of special insulating mass was made through which the larger ceramic tube passed. Fig. 1 shows one of the prepared samples for testing. In this figure, one can see: a sample (1), an external thermocouple (2), an alumina ceramic tube (3) and the special insulating mass cap for sealing the furnace (4). 


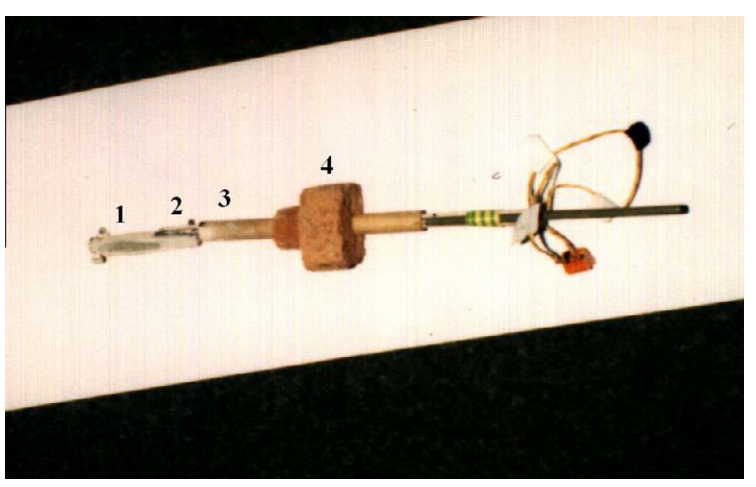

Fig. 1. The sample for testing.

A steel sample was also made, with the same size as the samples on which TBC systems were deposited to establish a temperature difference in the top and bottom surfaces of the substrate $\Delta T_{s}$. Temperature difference through the layers, $\Delta T_{T B C}$, perpendicular to the surface of the substrate, is obtained as the difference $\Delta T_{T B C}=\Delta T_{u}-\Delta T_{s}$. Investigation of thermal insulating properties of TBC (temperature drop in the layer depths) and the behaviour of layers in thermal cyclic conditions is done at $1200^{\circ} \mathrm{C}$. In order to perform sample testing, a differential thermocouple Pt/Rh-Pt was made from wire $0.3 \mathrm{~mm}$ thick; a dedicated software and hardware (AD converter) was used to convert the heat flux into electrical values. The equipment used for testing of samples is shown in Fig. 2.

The equipment consists of: a screen for tracking test results (1), a computer (2), an AD converter (3), a heating furnace (4), a tunnel for rapid cooling of the sample (5) and a sample for testing (6). The furnace in which the sample testing was done was calibrated at $1200^{\circ} \mathrm{C}$. The measuring was carried out with an error of $\pm 20^{\circ} \mathrm{C}$, due to temperature rise and fall while turning the furnace on and off. Before inserting the sample into the furnace, the temperature difference between the surface of the ceramic coating and the substrate bottom surface was $\Delta T_{u}=0$. After inserting the sample into the furnace, $\Delta T_{u}$ slowly begins to rise due to the heating of surface of the ceramic coating. The surface temperature of the coating increases more rapidly than the temperature of the base, due to

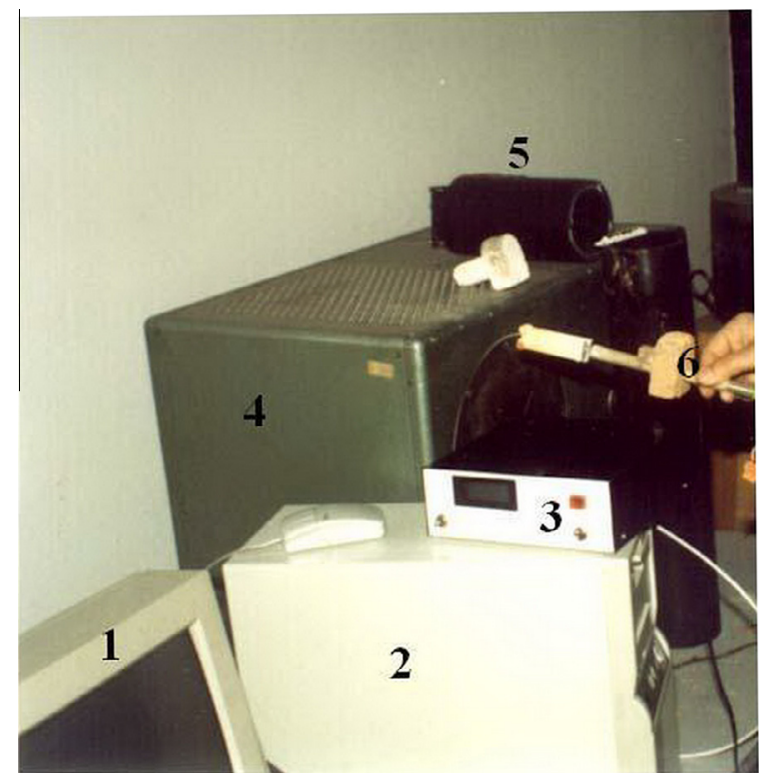

Fig. 2. Equipment for sample testing. ceramic coating insulation. $\Delta T_{u}$ value reaches a maximum when the temperature of the surface of the ceramic coating reaches $1200^{\circ} \mathrm{C}$, and then decreases because the temperature of substrate rises until it reaches the furnace temperature.

After equalizing the temperature, the samples are extracted from the furnace and rapidly cooled in the tunnel with a fan to a temperature of $160-180^{\circ} \mathrm{C}$. The time for heating of the samples was two minutes, while cooling lasted three minutes. The number of completed cycles depended on the occurrence of macro cracks.

Microstructures of the TBC systems were analyzed after thermal cyclic tests with an optical microscope (OM). Samples were prepared using the standard method of grinding and polishing, without etching.

Measuring of microhardness of layers of the TBC system after thermal cyclic tests was performed using a Vickers diamond pyramid indenter and 100 gram load $\left(\mathrm{HV}_{0.1}\right)$. The measuring was carried out in the direction along the lamellae in the middle and at the ends of the sample. At all three sites, five value readings were conducted and averaged subsequently. The values of microhardness after thermal cyclic tests were compared with the values of hardness before the tests.

\section{Results and discussion}

On the surfaces of all the ceramic coatings in deposited condition, identified networks of microcracks were examined using scanning electron microscopy (SEM). Presence of networks of microcracks on the surfaces of the ceramic coatings is the result of stress occurring during deposition of molten powder particles. Stresses on the surface of the deposited ceramic particles depend on the temperature at which the molten particle droplets are extinguished, particle hardening speed, substrate temperature and the ratio of thermal expansion coefficients of substrate and coating. The presence of microcracks on the surface of the deposited ceramic particles was described by Vardelle et al. [21] and the cause of their occurrence explained. This type of error is something that can not be avoided. The causes of the microcracks are stresses resulting from thermal gradients in the particles during cooling and differences of the expansion coefficients of layers. The substrate and the previously deposited layer restrict shrinking of the deposited particle after extinguishing. Another reason is the difference in thermal expansion of deposits and substrate during cooling of deposits to the substrate temperature. Figs. 3-5 show microcracks on the surfaces of ceramic particles $\mathrm{ZrO}_{2} \mathrm{MgO}, \mathrm{ZrO}_{2} \mathrm{Y}_{2}$ $\mathrm{O}_{3}$ and $\mathrm{ZrO}_{2} \mathrm{CeO}_{2} \mathrm{Y}_{2} \mathrm{O}_{3}$ deposited on preheated samples.

The most prominent networks of microcracks were present on the surface of the completely molten ceramic $\mathrm{ZrO}_{2} \mathrm{MgO}$ particles

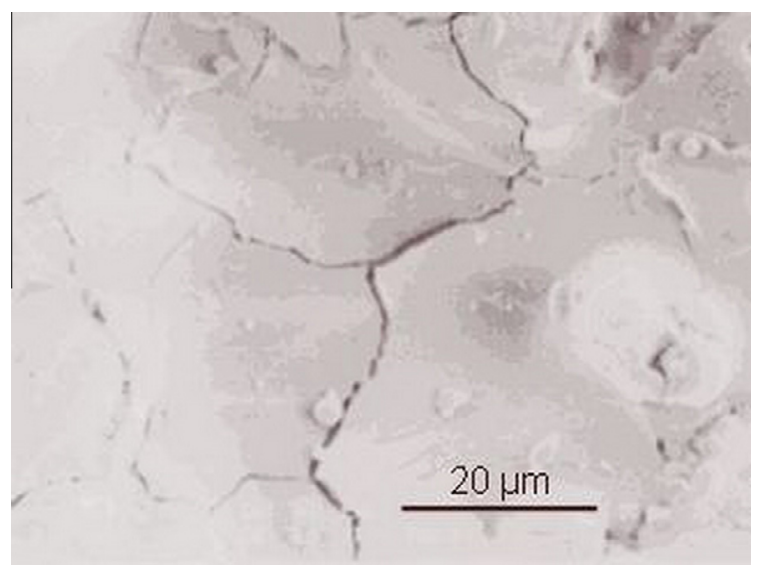

Fig. 3. SEM photomicrographs $\mathrm{ZrO}_{2} \mathrm{MgO}$ surface. 


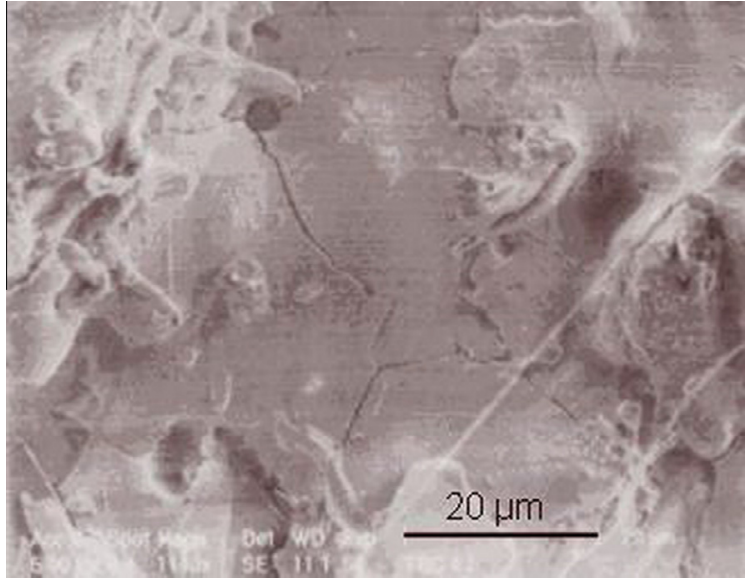

Fig. 4. $\mathrm{SEM}$ photomicrographs $\mathrm{ZrO}_{2} \mathrm{Y}_{2} \mathrm{O}_{3}$ surface.

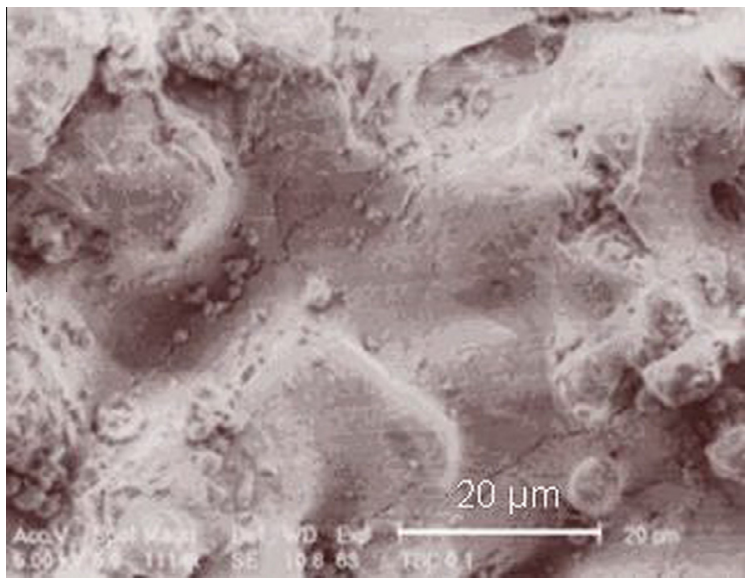

Fig. 5. SEM photomicrographs $\mathrm{ZrO}_{2} \mathrm{CeO}_{2} \mathrm{Y}_{2} \mathrm{O}_{3}$ surface.

(Fig. 3). For completely molten particles there is a greater temperature difference between the particles that are cooled on the surface of the coating and the previously deposited layers. Also, there is a greater difference in the expansion coefficients between the substrate and the surface layer of the coating. Therefore, the ceramic $\mathrm{ZrO}_{2} \mathrm{MgO}$ particles on the surface of the coating are exposed to greater tensile stresses which are opposing the particle contracting during cooling [21]. On the micrograph, it is clearly shown that the molten particle in collision with the base is properly deformed, it is almost smooth, and that compared to the other two ceramic particles has the highest degree of plastic deformation.

Investigating differences between the temperature at the top and bottom surface of the substrate thickness $1.5 \mathrm{~mm}$, a drop in temperature $\Delta T_{s}=150{ }^{\circ} \mathrm{C}$ was measured. The values of temperature difference $\Delta T_{u}$ through the tested samples for TBC system 1 $\left(\mathrm{NiCrAlCoY} \mathrm{O}_{3} / \mathrm{ZrO}_{2} \mathrm{MgO}\right)$ are shown in Fig. 6, for TBC system 2 ( $\mathrm{NiCrAlCoY} \mathrm{O}_{3} / \mathrm{ZrO}_{2} \mathrm{Y}_{2} \mathrm{O}_{3}$ ) in Fig. 7 and for TBC system 3 (NiCrAl$\left.\mathrm{CoY}_{2} \mathrm{O}_{3} / \mathrm{ZrO}_{2} \mathrm{CeO}_{2} \mathrm{Y}_{2} \mathrm{O}_{3}\right)$ in Fig. 8. The average value of the temperature drop through samples $(2-1) /(2-2)$ for TBC system 1 $\left(\mathrm{NiCrAlCoY} \mathrm{O}_{3} / \mathrm{ZrO}_{2} \mathrm{MgO}\right)$ is $\Delta T=460{ }^{\circ} \mathrm{C}$, through samples (3-1)/ (3-2) for $\mathrm{TBC}$ system $2\left(\mathrm{NiCrAlCoY}_{2} \mathrm{O}_{3} / \mathrm{ZrO}_{2} \mathrm{Y}_{2} \mathrm{O}_{3}\right)$ is $\Delta T=390{ }^{\circ} \mathrm{C}$ and through samples $(4-1) /(4-2)$ for TBC system $3\left(\mathrm{NiCrAlCoY}_{2} \mathrm{O}_{3} /\right.$ $\left.\mathrm{ZrO}_{2} \mathrm{CeO}_{2} \mathrm{Y}_{2} \mathrm{O}_{3}\right)$ is $\Delta T=560^{\circ} \mathrm{C}$.

The real value of temperature drop through TBC system 1 is $\Delta T_{T B C 1}=460^{\circ} \mathrm{C}-150^{\circ} \mathrm{C}=310^{\circ} \mathrm{C}$, through $\mathrm{TBC}$ system 2 it is $\Delta T_{T B C-2}=390^{\circ} \mathrm{C}-150^{\circ} \mathrm{C}=240^{\circ} \mathrm{C}$ and through $\mathrm{TBC}$ system 3 it

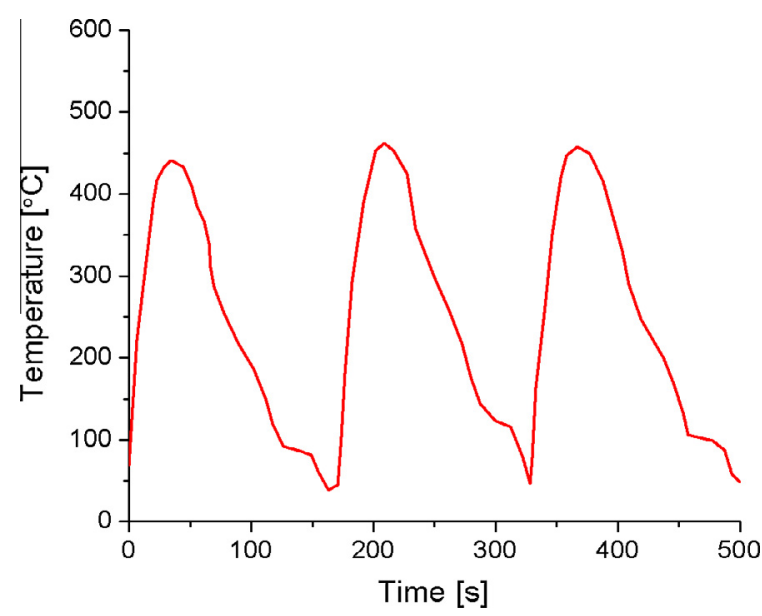

Fig. 6. $\Delta T$ for TBC system 1 and samples (2-1)/(2-2).

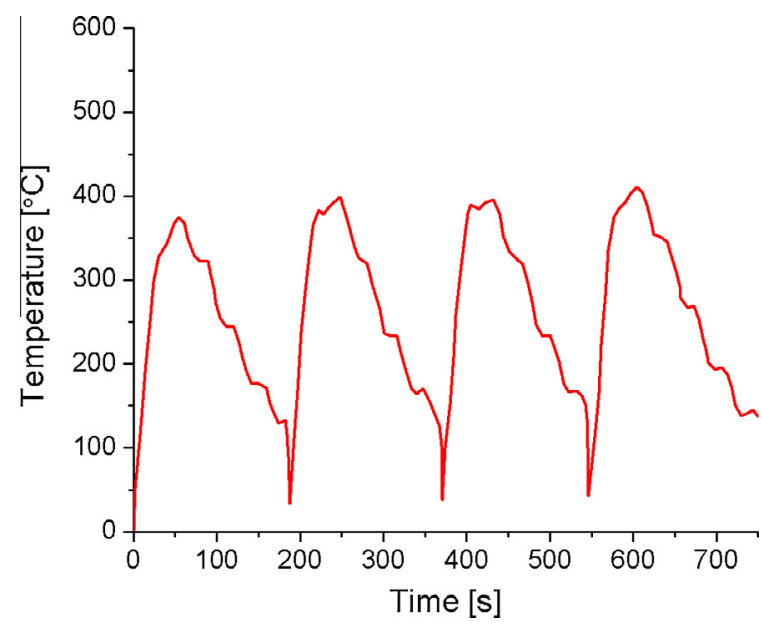

Fig. 7. $\Delta T$ for TBC system 2 and samples (3-1)/(3-2).

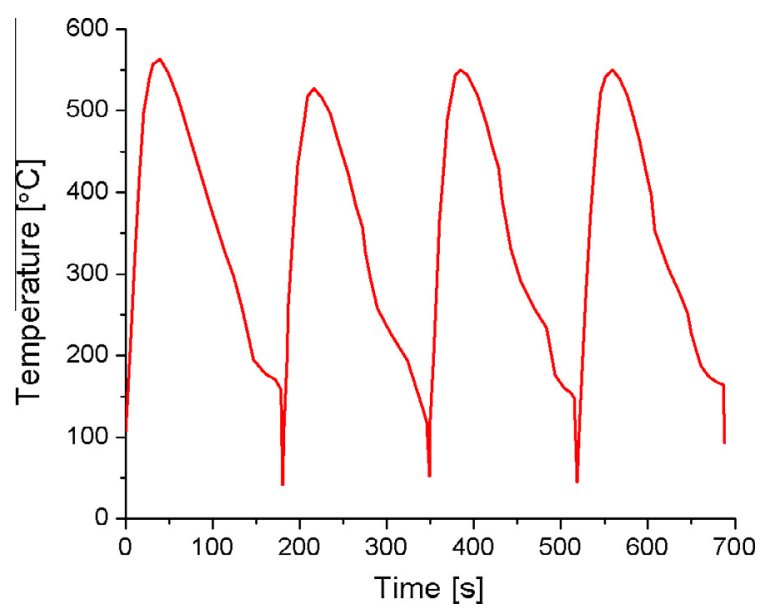

Fig. 8. $\Delta T$ for TBC system 3 and samples (4-1)/(4-2).

is $\Delta T_{T B C-3}=560^{\circ} \mathrm{C}-150{ }^{\circ} \mathrm{C}=410^{\circ} \mathrm{C}$. All types of $\mathrm{TBC}$ systems have lowered the actual temperature of the top surface of the substrate for $\Delta T=240-410^{\circ} \mathrm{C}$. The best insulation properties and the most prominent drop in temperature are obtained for ceramic layers $\mathrm{ZrO}_{2} \mathrm{CeO}_{2} \mathrm{Y}_{2} \mathrm{O}_{3}$, although these layers had the lowest proportion of pores and were the most dense. 


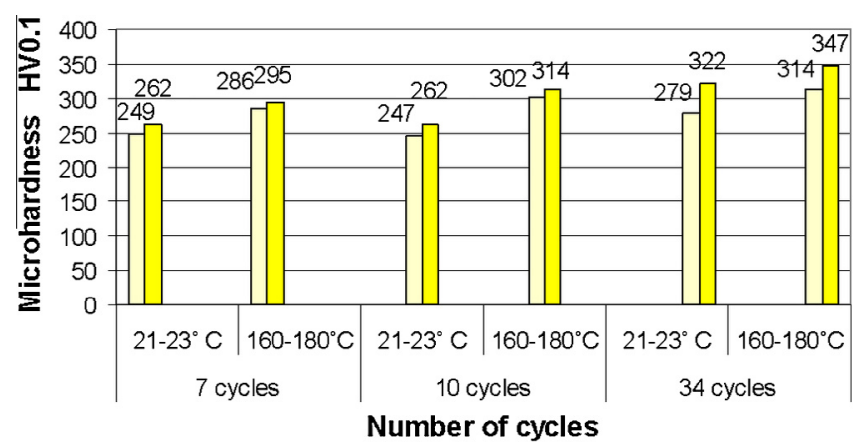

Fig. 9. Microhardness of $\mathrm{NiCrAlCoY}_{2} \mathrm{O}_{3}$ layers depending on the number of cycles.

It is well known that thicker layers have a lower thermal conductivity and a lower temperature drop through the layer. The cause of such low thermal conductivity and increased temperature drop through $\mathrm{ZrO}_{2} \mathrm{CeO}_{2} \mathrm{Y}_{2} \mathrm{O}_{3}$ layers is an extremely low thermal conductivity coefficient of ceramics: $0.9 \mathrm{~W} / \mathrm{m}^{\circ} \mathrm{C}$. Ceramic layers $\mathrm{ZrO}_{2} \mathrm{MgO}$, although more dense than $\mathrm{ZrO}_{2} \mathrm{Y}_{2} \mathrm{O}_{3}$, showed better insulating properties due to thicker $84 \mu \mathrm{m}$ layers. The measured values indicate that thermal conductivity coefficient and the ceramic layer thickness have more significant impact on the insulating properties of ceramic layers than the amount of pores.

The microhardness values of bond coating $\mathrm{NiCrAlCoY}_{2} \mathrm{O}_{3}$ layers before and after thermal cyclic tests are shown in Fig. 9. Lower values of microhardness are related to bond coatings in the deposited state, and higher values after completion of thermal cycles.

The measured values of microhardness are directly related to the number of thermal cycles performed. The largest increase in microhardness is observed for the layers with the highest number of cycles performed (34). The cause of a larger increase in the microhardness of samples was prolonged exposure to high temperature. At $1200{ }^{\circ} \mathrm{C}$ inter-diffusion of chemical elements occurs due to different content of chemical elements in the coating and the substrate and the diffusion of oxygen from the atmosphere through the porous ceramic layers.

Occurrence of oxygen diffusion into the bond coating and diffusion of iron from the substrate into the bond coating was described by $\mathrm{Zhu}$ et al. [22]. In the coating, there is probably present a $\mathrm{Fe}_{2} \mathrm{O}_{3}$ type oxide due to Fe diffusion from the substrate into the coating and Fe reaction with oxygen that diffuses into the coating [22].

The microhardness of ceramic layers $\mathrm{ZrO}_{2} \mathrm{MgO}, \mathrm{ZrO}_{2} \mathrm{Y}_{2} \mathrm{O}_{3}, \mathrm{ZrO}_{2}$ $\mathrm{CeO}_{2} \mathrm{Y}_{2} \mathrm{O}_{3}$ before and after thermal cyclic tests is shown in Fig. 10.

Lower values of microhardness are related to ceramic coatings in the deposited state. For all types of ceramic coatings, microhardness values were increased. The highest values and increase of microhardness are obtained for $\mathrm{ZrO}_{2} \mathrm{MgO}$ layers. For a small

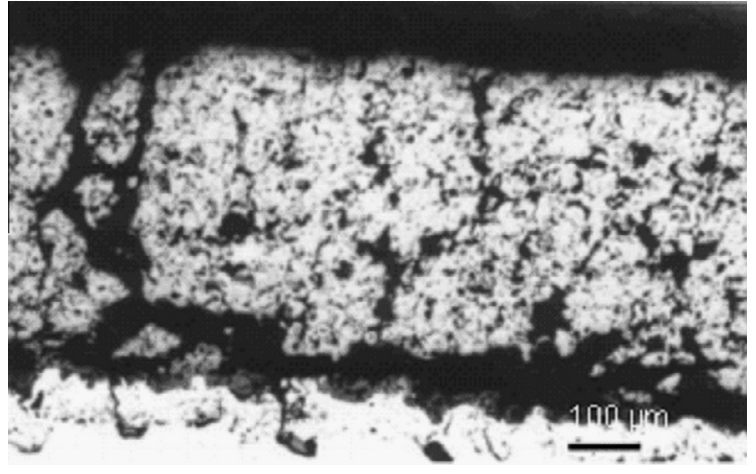

Fig. 11. Microstructure of the TBC system 1 after 7 cycles.

number of completed cycles (7), ceramic layer $\mathrm{ZrO}_{2} \mathrm{MgO}$ showed microhardness values from 916 to $1027 \mathrm{HV}_{0.1}$. This indicates that the oxide $\mathrm{MgO}$ at $1200{ }^{\circ} \mathrm{C}$ is a bad stabilizer for $\mathrm{ZrO}_{2}$ ceramics and that there is a ceramic $\mathrm{ZrO}_{2} \mathrm{MgO}$ layer fatigue due to rapid transformation of the tetragonal phase into a monoclinic phase $(\mathrm{t} \rightarrow \mathrm{m})$. The increase in microhardness of the ceramic layer $\mathrm{ZrO}_{2} \mathrm{MgO}$ deposited on a cold substrate was $422 \mathrm{HV}_{0.1}$, and on the preheated substrate $379 \mathrm{HV}_{0.1}$. Higher growth of microhardness is also affected by higher pore content (24\%). Larger contents of porosity significantly affect the level of developed thermal stresses in ceramic coatings and accelerated fatigue of coatings subjected to thermal stresses. Ceramics $\mathrm{Y}_{2} \mathrm{O}_{3}$ and $\mathrm{CeO}_{2}$ have proven to be more reliable stabilizers for ceramics $\mathrm{ZrO}_{2}$.

Microhardness increase is not as high as in TBC system 1, which indicates that in these coatings there was no fatigue or complete transformation of the tetragonal phase into the monoclinic phase $(\mathrm{t} \rightarrow \mathrm{m})$. The increase in microhardness of ceramics $\mathrm{ZrO}_{2} \mathrm{Y}_{2} \mathrm{O}_{3}$ for 34 completed cycles was $62 \mathrm{HV}_{0.1}$ and $43 \mathrm{HV}_{0.1}$. A larger increase was obtained for the layers deposited on a cold substrate with a higher content of pores $-29 \%$. For layers $\mathrm{ZrO}_{2} \mathrm{CeO}_{2} \mathrm{Y}_{2} \mathrm{O}_{3}$, increase in microhardness for 10 completed cycles was low, $46 \mathrm{HV}_{0.1}$ and $43 \mathrm{HV}_{0.1}$. A slightly greater increase in microhardness was observed in layers with higher pore content (18\%). Otherwise, $\mathrm{ZrO}_{2} \mathrm{CeO}_{2} \mathrm{Y}_{2} \mathrm{O}_{3}$ layers were deposited with the smallest pore content. Generally, for all TBC systems, greater increase in microhardness was observed for layers deposited on cold substrates with higher pore content.

Metallographic examination of samples with deposited TBC systems have shown that the high thermal load at $1200^{\circ} \mathrm{C}$ caused the deformation of the substrate, growth and expansion of existing microcracks into macrocracks, and the emergence of new microcracks in the ceramic layers. Figs. 11-13 show the microstructure of TBC systems deposited on preheated samples after thermal cyclic tests. Generally, for all TBC systems there was no flaking of lay-

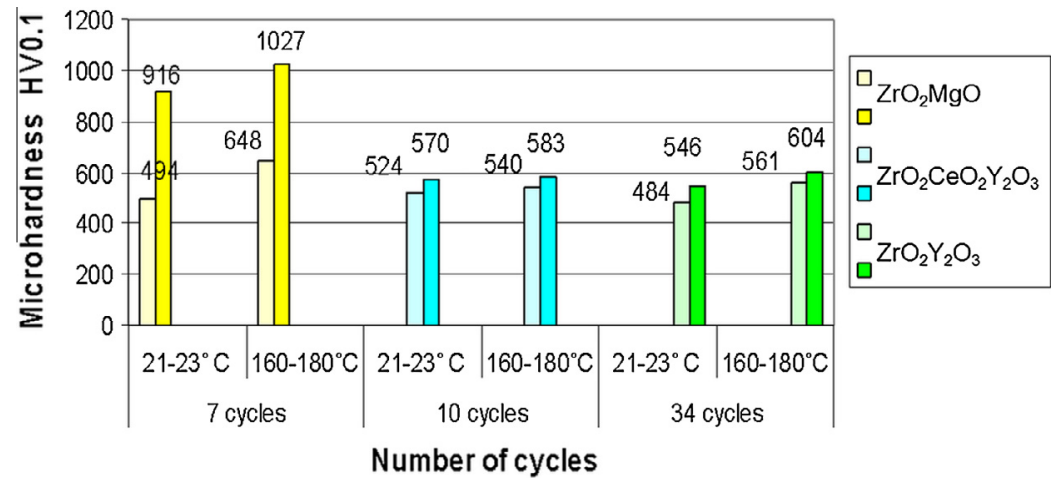

Fig. 10. Microhardness of ceramic layers depending on the number of cycles. 


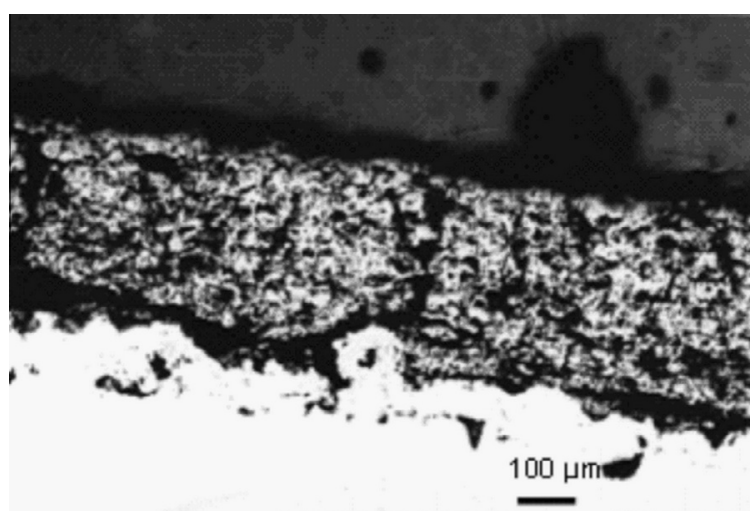

Fig. 12. Microstructure of the TBC system 2 after 34 cycles.

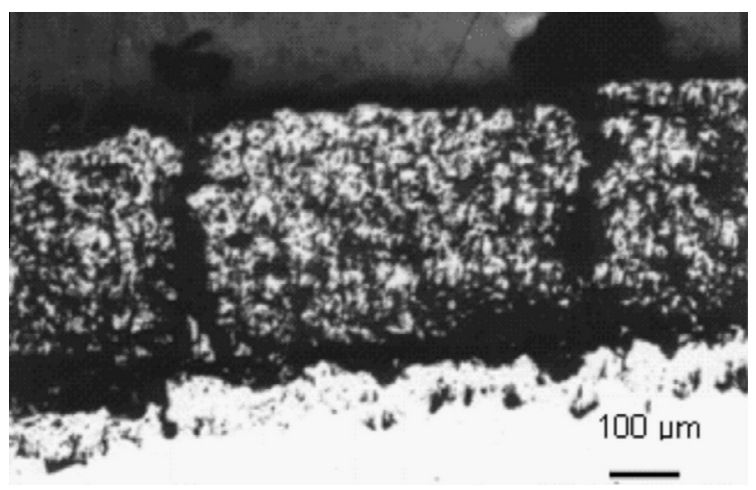

Fig. 13. Microstructure of the TBC system 3 after 10 cycles.

ers off the substrate, no separation of layers at the edges of samples and no separation of ceramic layers in depth of coatings.

In all of the ceramic layers, long cracks that run parallel through the ceramic layers near the interface with the bond layers are observed, as well as vertical macrocracks which extend from the surface of the coating to the bond layers. The cracks are formed due to thermal stresses caused by phase transformation followed by volume change and deformation of the substrate. Inter-lamellar pores that enhance the effect of thermal insulation are also a source of breaking through the layers, due to the release of residual stresses. Fracture initiation and development in homogeneous and heterogeneous materials is analyzed in the literature using different experimental and numerical techniques, some of which are shown in [23-25]. The influence of cracks in coatings on the structural behaviour is considered in [26-28].

The worst microstructure is exhibited by the ceramic layer $\mathrm{ZrO}_{2} \mathrm{MgO}$. On the cross section, it is clear that in the ceramic layer at depth, between two macrocracks, destruction of ceramics occurred due to the thermal cyclic fatigue (Fig. 11). In the ceramic layer $\mathrm{ZrO}_{2} \mathrm{Y}_{2} \mathrm{O}_{3}$ the largest number of macrocracks and microcracks were observed due to the largest number of completed cycles (34). The $\mathrm{ZrO}_{2} \mathrm{CeO}_{2} \mathrm{Y}_{2} \mathrm{O}_{3}$ layers in the microstructure had the widest vertical macrocracks, since this type of ceramics (compared to the other two) has the lowest linear expansion coefficient $\left(8.5 \times 10^{-6} 1 /{ }^{\circ} \mathrm{C}\right)$ with respect to the substrate [20]. The linear expansion coefficient of $\mathrm{ZrO}_{2} \mathrm{MgO}$ is $11 \times 10^{-6} 1 /{ }^{\circ} \mathrm{C}$, and of ceramics $\mathrm{ZrO}_{2} \mathrm{Y}_{2} \mathrm{O}_{3}$ is $10 \times 10^{-6} 1 /{ }^{\circ} \mathrm{C}[18,19]$.

\section{Conclusions}

Results of experimental examination of the TBC system 1 $\left(\mathrm{NiCrAlCoY}_{2} \mathrm{O}_{3} / \mathrm{ZrO}_{2} \mathrm{MgO}\right), \quad \mathrm{TBC}$ system $2\left(\mathrm{NiCrAlCoY}_{2} \mathrm{O}_{3} / \mathrm{ZrO}_{2}\right.$
$\left.\mathrm{Y}_{2} \mathrm{O}_{3}\right)$ and $\mathrm{TBC}$ system $3\left(\mathrm{NiCrAlCoY}_{2} \mathrm{O}_{3} / \mathrm{ZrO}_{2} \mathrm{CeO}_{2} \mathrm{Y}_{2} \mathrm{O}_{3}\right)$ enable evaluation of insulating properties and behaviour of coatings in thermal cyclic conditions. It is shown that stabilizers $\mathrm{MgO}, \mathrm{Y}_{2} \mathrm{O}_{3}$ and $\mathrm{CeO}_{2}$ have great influence on the stability of $\mathrm{ZrO}_{2}$, insulating properties and behaviour of the TBC systems in cyclic conditions.

On the surfaces of all ceramic coatings in deposited state, there was a network of microcracks as a result of stress that occurs during deposition. The causes of formed microcracks are stresses arising from the difference of thermal gradients in the particles during cooling and expansion coefficients of the previously deposited layers. Substrate with a pre-deposited layer limits the contraction of deposited particles after extinguishing.

The best insulation properties and the largest drop in temperature $\Delta T=410^{\circ} \mathrm{C}$ were obtained for ceramic layers $\mathrm{ZrO}_{2} \mathrm{CeO}_{2} \mathrm{Y}_{2} \mathrm{O}_{3}$, although they had the smallest proportion of pores and were the most dense. The worst insulation properties, $\Delta T=240^{\circ} \mathrm{C}$, are obtained for ceramic layers $\mathrm{ZrO}_{2} \mathrm{Y}_{2} \mathrm{O}_{3}$, because they were thinner than the previous two layers. The thermal conductivity and thickness of the ceramic layers had the most significant effect on the insulating properties of ceramic layers.

The microhardness values of bond layers $\mathrm{NiCrAlCoY}_{2} \mathrm{O}_{3}$ after thermal cyclic tests were directly related to the number of thermal cycles performed. The largest increase in microhardness was obtained for layers with the highest number of cycles performed. The cause of the increase in microhardness is exposing samples to high temperatures, which leads to oxygen diffusion and interdiffusion of the chemical elements on the interface between the coating and substrate.

Of the ceramic coatings, the largest increase of microhardness was observed for $\mathrm{ZrO}_{2} \mathrm{MgO}$ layers with the lowest number of completed cycles. Oxide $\mathrm{MgO}$ proved to be a bad stabilizer for $\mathrm{ZrO}_{2}$ ceramics at $1200{ }^{\circ} \mathrm{C}$. Ceramics $\mathrm{ZrO}_{2} \mathrm{Y}_{2} \mathrm{O}_{3}$ and $\mathrm{ZrO}_{2} \mathrm{CeO}_{2} \mathrm{Y}_{2} \mathrm{O}_{3}$ with a larger number of completed cycles showed significantly lower microhardness increase, indicating that $\mathrm{Y}_{2} \mathrm{O}_{3}$ and $\mathrm{CeO}_{2}$ and $\mathrm{Y}_{2} \mathrm{O}_{3}$ together are good stabilizers for $\mathrm{ZrO}_{2}$ ceramics. The increase in microhardness is also influenced by the higher content of pores in the coating. Higher porosity significantly affects the level of stress in the ceramic coatings that accelerate fatigue of coating subjected to thermal stresses.

Metallographic studies showed that the high thermal load at $1200{ }^{\circ} \mathrm{C}$ caused the deformation of the substrate, the growth and expansion of existing microcracks into macrocracks and the emergence of new microcracks in the ceramic layers. Ceramic layer $\mathrm{ZrO}_{2} \mathrm{MgO}$ showed the worst microstructure. Microstructure indicates that in some places there was destruction and fatigue of the ceramic due to tetragonal phase transformation to monoclinic phase $(\mathrm{t} \rightarrow \mathrm{m})$. The largest number of macrocracks and microcracks were present in the ceramic layer $\mathrm{ZrO}_{2} \mathrm{Y}_{2} \mathrm{O}_{3}$ with the maximum number of completed cycles. The most pronounced vertical macrocracks were present in $\mathrm{ZrO}_{2} \mathrm{CeO}_{2} \mathrm{Y}_{2} \mathrm{O}_{3}$ layers because this type of ceramics has the lowest thermal expansion coefficient compared to the substrate.

\section{Acknowledgements}

The authors are thankful for the financial support from the Ministry of Education and Science of the Republic of Serbia (National projects ON 174004, TR 34016).

\section{References}

[1] Huda Z, Edi P. Materials selection in design of structures and engines of supersonic aircrafts: a review. Mater Des 2013;46:552-60.

[2] Durat M, Kapsiz M, Nart E, Ficici F, Parlak A. The effects of coating materials in spark ignition engine design. Mater Des 2012;36:540-5. 
[3] Lee CH, Kim HK, Choi HS, Ahn HS. Phase transformation and bond coat oxidation behavior of plasma-sprayed zirconia thermal barrier coating. Surf Coat Technol 2000;124:1-12.

[4] Lee DB, Lee C. High-temperature oxidation of $\mathrm{NiCrAlY} /\left(\mathrm{ZrO}_{2}-\mathrm{Y}_{2} \mathrm{O}_{3}\right.$ and $\mathrm{ZrO}_{2}-$ $\mathrm{CeO}_{2}-\mathrm{Y}_{2} \mathrm{O}_{3}$ ) composite coatings. Surf Coat Technol 2005;193:239-42.

[5] Boutz MMR, Winnubst AJA, Burggraaf AJ. Yttria-ceria stabilized tetragonal zirconia polycrystals: sintering, grain growth and grain boundary segregation. J Eur Ceram Soc 1994;13:89-102.

[6] Chevalier J, Gremillard L, Virkar AV, Clarke DR. The tetragonal-monoclinic transformation in zirconia: lessons learned and future trends. J Am Ceram Soc 2009;92:1901-20.

[7] Johner G, Schweitzer KK. Thermal barrier coatings for jet engine improvement Thin Solid Films 1984;119:301-15.

[8] Garvie RC, Hannink RHJ, Pascoe RT. Ceramic steel? Nature 1975;258:703-4.

[9] Garvie RC. Zirconium dioxide and some of its binary systems. In: Alper AM editor. High-temperature oxides, vol. 5-II. New York: Academic Press; 1970. p. 117-66.

[10] Basler B, Buergel R, Hoffelner W. On the behaviour of overlay coatings in stationary gas turbines. In: Proc of 1 st int conf on plasma surface engineering vol. 1. Germisch - Partenkirchen; 1988. p. 347.

[11] Celik E, Mutlu HI, Avci E, Hascicek YS. $\mathrm{Y}_{2} \mathrm{O}_{3}-\mathrm{ZrO}_{2}$ insulation coatings on AgMg sheathed $\mathrm{Bi}-2212$ superconducting tapes by sol-gel technique. IEEE Trans Appl Superconduct 2000;10:1329-32.

[12] Celik E, Mutlu HI, Hascicek YS. Electrical properties of high temperature insulation coatings by sol-gel method for magnet technology. IEEE Trans Appl Superconduct 2000;10:1341-4.

[13] Celik E, Avci E, Hascicek YS. High temperature sol-gel insulation coatings for HTS magnets and their adhesion properties. Physica C 2000;340:193-202.

[14] Demirkiran AS, Celik E, Yargan M, Avci E. Oxidation behaviour of functionally gradient coatings including different composition of cermets. Surf Coat Technol 2001;142-144:551-6.

[15] Moon J, Choi H, Kim H, Lee C. The effects of heat treatment on the phase transformation behavior of plasma-sprayed stabilized $\mathrm{ZrO}_{2}$ coatings. Surf Coat Technol 2002;155:1-10.
[16] Guo H, Yao R, Zhou L. Plasma-sprayed thermal barrier coatings with segmentation cracks. In: $\mathrm{Xu} H$, Guo $\mathrm{H}$, editors. Thermal barrier coatings. Cambridge: Woodhead Publishing; 2011. p. 161-74.

[17] Metco 461 nickel chromium-aluminum-cobalt-yttria composite powder. Technical Bulletin 10-315. Sulzer Metco; 2000.

[18] Metco 210 magnesium zirconate powder. Technical Bulletin 10-108. Sulzer Metco; 2000.

[19] Metco 202NS zirconium oxide composite powder. Technical Bulletin 10-107. Sulzer Metco; 2000.

[20] Metco 205NS pre-alloyed ceria-yttria stabilized zirconia powder. Technical Bulletin 10-338. Sulzer Metco; 2000.

[21] Verdelle M, Besson JL. $\Gamma$ alumina obtained by arc plasma spraying: a study of the optimization of spraying conditions. Ceram Int 1981;7:48-54.

[22] Zhu C, Wu X, Wu Y, Liang G. The effect of initial oxidation on long-term oxidation of NiCoCrAlY alloy. Engineering 2010;2:602-7.

[23] Zerbst U, Heinimann M, Dalle Donne C, Steglich D. Fracture and damage mechanics modelling of thin-walled structures - an overview. Eng Fract Mech 2009;76:5-43.

[24] Rakin M, Medjo B, Gubeljak N, Sedmak A. Micromechanical assessment of mismatch effects on fracture of high-strength low alloyed steel welded joints. Eng Fract Mech 2013;109:221-35.

[25] Likeb A, Gubeljak N, Matvienko Y. Finite element estimation of the plastic $\eta_{\mathrm{p}}$ factors for pipe-ring notched bend specimen using the load separation method. Fatigue Fract Eng Mater Struct 2014;37:1319-29.

[26] Matoy K, Detzel T, Müller M, Motz C, Dehm G. Interface fracture properties of thin films studied by using the micro-cantilever deflection technique. Surf Coat Technol 2009;204:878-88.

[27] Xu R, Fan XL, Zhang WX, Song Y, Wang TJ. Effects of geometrical and material parameters of top and bond coats on the interfacial fracture in thermal barrier coating system. Mater Des 2013;47:566-74.

[28] Zhang XC, Xu BS, Wang HD, Jiang Y, Wu YX. Residual stress redistribution within high-temperature coatings due to surface cracks. Mater Des 2007;28:2336-43. 